\title{
Paleo-Odontology
}

\section{Teeth as Chroniclers of Life Histories}

\author{
G. H. Sperber
}

BSc (Hons), BDS, MSc, PhD, FICD, FRSSAf, Dr Med.Dent (Hon)

Faculty of Medicine \& Dentistry, University of Alberta, Edmonton, AB, Canada.

gsperber@ualberta.ca

*Corresponding Author: G. H. Sperber, Faculty of Medicine \& Dentistry, University of Alberta, Edmonton $A B$, Canada.

Abstract

Teeth are the most enduring components of postmortem skeletal remains of past and present fauna. They reveal the components of the previous contemporaneous biospheres and the development of different diets and evolutionary advances.

Teeth make great witnesses as they never deceive and they never forget. Teeth chronicle and epitomize life events. Teeth are time capsules of lives lived.

Keywords: Teeth; Paleo-odontology; Paleobiology; Diets; Dentistry; Archives.

\section{INTRODUCTION}

The need to capture, incise, triturate and masticate food created the different categories of teeth into incisors, canines, premolars and molars. The complex history of this evolution is captured in evolution's bite (Ungar PS 2014; 2017; Guatelli-Steinberg 2016). Analysis of hominin dental anatomy is a keystone of paleo-odontological research. The embryological origins of hominid dental diversity are explored in virtual evo-devo models of molar tooth development (Ortiz A, Bailey SE et al. 2018). Canine size reduction from apes to man reflects social structural changes; molar size reduction reflects dietary changes; less chewing results in smaller jaws, leading to tooth impactions and malocclusions. (Eng, Lieberman, Zinc, Peters 2013) Differential grades of wear between early erupting and later erupting teeth, e.g. 6 year-old first molars, 12 year-old second molars and 18 yearold third molars provide clues as to the abrasion by foods consumed. Well-worn first molars combined with unworn third molars in the same dentition is indicative of a prolonged period of adolescence between childhood at six years and adulthood at 18-20 years, hence "wisdom" teeth. (Fig. 1). Eruption ages are indicators of chronicity and maturation speed.

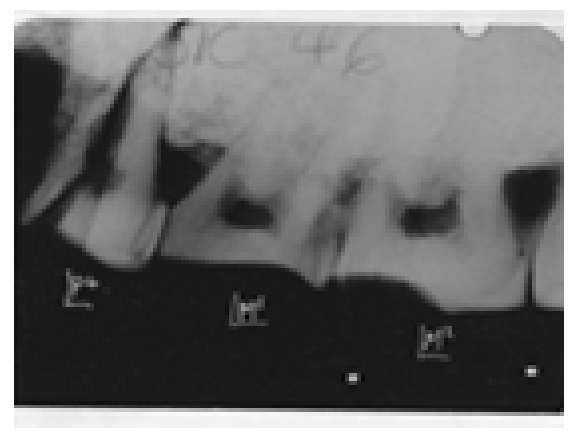

Figure 1. Paranthropus robustus. Kromdraai

Radiograph of Left maxillary teeth. An unusual pattern of severe wear confined to the mesial half of M2 that requires explanation. The less worn distal half of this tooth and M3 suggests absence of the corresponding occluding mandibular M2 and M3. Thereby, unusual wear patterns reveal peculiar phenomena of attrition.

Teeth are our bridge to the past, as they are essentially ready-made fossils. While teeth are subject to the vagaries of the living while forming and performing their functions, they become enduring historiographic remnants of the biosphere they once occupied. Of all the components of fossil hominid remains, it is the dentition that offers the most incisive insights into the lifestyles of the protagonists investigated. The 
discovery of a lone deciduous tooth allowed for the confirmation of the Denisovan hominin species based on its mitochondrial DNA genome. (Slon V, Viola B,et al. 2017) Molecular biology detects extracted tooth treasures as determinants of species. The "foodprints" inscribed by tooth wear patterns allow for dietary interpretations, particularly "the Last Supper" consumed. Our teeth connect us to our Paleolithic ancestors by providing evidence of the manner of gnathostome jaw evolution (Kuratani S et al. 2013) and mastication with vertical and lateral excursions.

Teeth, by virtue of the kymographic incremental nature of odontogenesis, provide a photobiography of their life histories permanently imprinted on their structure. Teeth not only record the varying vicissitudes of their own composition, but also provide evidence of the diets of their owners. Furthermore, signs of prehistoric dental manipulation are permanently manifested in paleontological remains (Frayer DW, Monge J 2017).

The function of teeth as food acquisition facilitators and masticatory organs impacts on their structure revealed by odontographics. The roots of dental anthropology go deep (Guatelli-Steinberg 2018).

\section{The Paleontological Record}

The acquisition of nutrition to sustain life is fundamental to all living creatures, and the diversity of the means to obtain food provides the basis of the heterogeneity of food acquisition. The development of jaws from jawless ancestors is illuminated in jaw evolution (Zhu M, Ahlberg PE, Pan Z. 2016; Miyashita T 2016; Smith MM, Fraser GJ, Johansen Z. 2016). The evolutionary origins of capturing prey is dependent upon the development of crystalized structures that eventually became teeth. The permanence of odontolithic tissues provides the early evidence of organs devised for comestible acquisition (Sperber 2013). A tiny tooth plate in a 410 million year-old fossil fish indicated teeth evolved earlier than recently thought (Rucklin \& Donaghue 2015). The early development of rostrum saw -teeth in a fossil ray tests the classical theories of the evolution of vertebrate dentitions (Smith MM, Riley A et al.2015). Acanthoracid dental plates evolved from gnathal dermal specializations. At the dawn of vertebrate evolution, jaws evolved by spatial confinement of the most anterior pharyngeal (mandibular) arch (Miyashita 2015).
Thedentitions of extinctcreaturesprovideenlightening insights into their phylogenetic position, their paleobiology, diets, development and growth. The loss of teeth in avian evolution is traced in the revelations of the biology of the last toothed birds (Dumont M, Tafforeau P et al. 2016). The bird-like characteristics of the jaws and teeth of Troodontid theropods reveal the transition of the ancestral dinosaurian odontognathic apparatus to the avian gnathostomodeum (Currie PJ 1987). The transformations into beaked birds by the enlargement of the toothless premaxilla is illustrated by the mosaic assembly of the avian head (Field DJ, Hansen $M$ et al. 2018). These modifications of food acquisition undoubtedly reflect changes in the diets of these creatures (Padian K 2018).

Teeth evolved as specialization of the dermal denticles of shark shagreen and were continuously regenerative organs that utilized initial developmental genetic signaling pathways of $\mathrm{Hh}$, wnt/B catenin, Bmp and Fgf, which were redeployed in subsequent evolution (Rasch et al. 2016). Tooth replacement while retaining functional teeth being resorbed is revealed in a study of ceratopsin dental evolution ( $\mathrm{He} \mathrm{Y}$ et al. 2018). Continuous tooth replacement (polyphyodonty) requires regenerative capacity that can be superseded by acrodont monophyodont ontogeny (Haridy et al. 2018). Acrodonty does not inhibit tooth replacement by the typical pleurodont tooth implanation attachment. Thus, tooth implantation is a poor defining phylogenetic characteristic in tracing odontological evolutionary trajectory. The requirement of bone attachment for tooth replacement is not necessary, as demonstrated by mutation of the transcription factor sp7 (osterix) (Kague, Witten 2018).

\section{Dental Microwear}

The patterns of wear imprinted on the occlusal surfaces of teeth, "odontographics", are an invaluable resource of numerous aspects of paleobiology (Lucas PW 2013). Teeth inform the relationship of foods consumed by topographic analysis of occlusal surfaces (Klukkert ZS, Dennis JC et al. 2012). Dental wear results from attrition, erosion and abrasion, requiring identification of the etiological factors implicated (Burnett SE, Irish JD, Fong MR 2013). The diets of Plio-Pleistocene hominins can be elucidated from dental evidence (Ungar 2011). Characteristics of dental microwear can distinguish dietary and behavioral regimens related to the various habitats occupied (Mahoney P 2007; 
Krueger KL. Ungar P, Guatelli-Steinberg D et al. 2017; Percher A, Merceron G et al. 2018). The mechanisms and causes of wear in dental enamel can reconstruct hominin diets (Lucas PW, Omar R et al. 2013). Analysis of radiographs of fossil dentitions provides insights into the state of dental occlusion at death and possible dietary regimen practised (Sperber 2017). Dental caries can be used as a "foodprint" to identify dietary intakes of cariogenic foodstuffs.

The revelations of tooth wear provide evidence of dietary preferences that, in turn, are indicative of the paleoclimate and habitats. The role of the environment and the changes in the localities of fossilized dental reliquaries provide invaluable insights into climatic shifts. of all the dietary elements ingested, their transient evanescent isotopic signatures are permanently imprinted on the crystalline dental enamel, to be revealed by sophisticated isotopic detection. The isotopes of $\mathrm{C} 12$ and $\mathrm{C} 13$ carbon incorporated in tooth enamel while teeth are forming reveal dramatic changes in early hominin diets from C3 trees and shrubs to C4 grasses, sedges and succulents (Grine FE, Sponheimer M, Ungar P, Lee-Thorp et al. 2012;Choi 2013). Dietary variation corresponded with forest environments and protein meat resources (Fiorenza L, Benazzi S et al. 2011).

The paleoecological environment may be reconstructed to provide subsistence availability and insights into diets and practices by dental microwear texture analysis. Variations in the pattern and degree of tooth wear between populations are indicative of the abrasiveness of the diet and the use of teeth as tools (Kaidonis JA 2008). The earliest dental evidence of the use of a dental bit evidenced by the wear pattern on lower premolars (LPM2) is provided by archaeological material found on a domestic equid from the Early Bronze Age (Greenfield HJ, Shai I, Greenfield, et al. 2018). Differences in dental microwear texture complexity can differentiate species of Homo habilis from Homo erectus based on contrasts in these species' diets (Ungar PS, Krueger KL et al. 2012; Percher A, Merceron G, Akoue G et al. 2018). Analysis of the deep pits and dental chipping of Homo naledi teeth led to the conclusion that their diet was composed of hard and abrasive foods (Ungar PS, Berger LR .2018). Dental topographic analysis provides evidence of changing diets and shifting ecologies (Lopez-Torres S, Selig KR et al. 2017; Ungar PS, Hartgrove CL et al. 2017).
The curious correlation of shovel-shaped incisor teeth in northern Asians and Native Americans with sweat glands, hair shafts and mammary gland ducts can be attributed to varying expression of the EDAR gene that codes for ectodysplasin A receptor (Hlusko LJ, Carlson JP et al. 2018).

Insights into the weaning process from archeological remains provide an assessment of variations of food consumption during weaning. The microwear signatures expand upon cultural systems of subsistence practices of the past (Scott AM, Halcrow S 2017). The biomechanics of feeding movements of the jaws can be evinced from the shapes and serrated biting edges of teeth and microwear scratches, revealing different diet preferences among different dinosaur species (Torices A et al. 2018).The capability of recording the diets of extant species for future research is now available with in situ tooth sensors of diets consumed (Tseng P, Napier B, Garbarini L et al. 2018).

\section{ODONTOGENESIS}

Odontogenesis represents the unique transformation of a set of genetic codes into the dental tissues that are crystallized to form fossilized tissues within the lifetime of an individual. The endurance of fossilized teeth provides evidence of lifetime experiences after death. Moreover, the paleo-odontological record of the evolution of teeth provides an unparalleled kymographic record of ancient inheritances embedded within the developing dentition. Detailed dental anatomical features of fossil hominin teeth provide evidence of the taxonomy, phylogeny and paleobiology of extinct species (Ortiz A, Bailey SE et al. 2018).

Dentitions initially evolved as specialized surface shagreen overlying the jaws that provided a succession of generations of teeth. Polyphyodont species, e.g. sharks have a permanent continuous dentigerous lamina, providing endless successions of replacements of shed teeth. (Rasch LJ et al. 2016). The continuous initiation of new teeth is determined by Wnt/Bcatenin and FGF signaling (Liu C, Gu S, Sun C et al. 2013). The differentiation of repetitively shaped teeth into diverse shapes of incisors, canines, premolars and molars was reported in a new genus and species of an eutriconodont mammal (Hou S, Meng J 2014). The development of cyclic shedding of teeth was demonstrated by Chen et al. (2017). In diphyodont species, the dental lamina disintegrates and regresses after initiation of the second generation. A 
genetic based mutation limited the succession to two generations, the primary and secondary dentitions (Butchova M, Stembirek J, Glocova et al.: 2012) Minor alterations in the way that genes code for complex features can result in different dental configurations. The occurrence of supernumerary teeth involves multiple genes (Kunotoi W, Ananpornruedo P et al. 2017).

The progressive nature of odontogenesis records ontogenetic life history, diet, paleoseasonality events and behavior. The static images of mineral density variations embedded in enamel histology can reveal much of the developmental history of an individual (Green DR, Green GM, Colman AS et al. 2017). Strontium isotope analysis of teeth can provide details of the habitat, mobility and growth characteristics of a species (Sillen A, Balter V 2018). The incorporation of varying quantities of isotopes of carbon as C12 or C14 reflecting the nature of grasses or sedges and leaves in the consumed diet provide information on the changing climatic conditions of the biosphere of the inhabitants (Sponheimer M. et al. 2013)

The embryonic dental lamina is the source of tooth germs that bud off at genetically predetermined intervals (Ahtiainen L, Uski I, Thesleff I, Mikkola. ML 2016). Induction of FGF signaling initiates tooth formation(BalicA, ThesleffI.2015). Thelongevity of the lamina determines the number of dental generations. Thus, monophyodont species, e.g. mice, have no replacement dental lamina and provides but a single generation of teeth. Polyphyodont species, e.g. sharks, have a permanent continuous dental lamina, providing an endless succession of replacement teeth. The floors of the oceans are littered with shed shark teeth. In diphyodont species, the dental lamina disintegrates and regresses after initiation of the second tooth generation. Incomplete disintegration leads to dental cyst formation, linked to ameloblastomas and to rare third generation successional teeth. Investigating the processes of lamina disintegration after the second generation, resulting in diphyodonty, may provide indications for possible future replacement of lost teeth.

\section{Dental Calculus}

The deposits of dietary components that become embedded in the sediment of dental calculus that is retained in recovered fossil dentitions provide an avalanche of invaluable resources of information on paleobiology. Ancient dietary patterns of different cultural periods are revealed by analysis of the mineralized deposits adhering to fossil teeth. (lieverse
AR. 1999). Particles and archeobotanical debris that would otherwise not be preserved in the acheological record can be incorporated into mineralizing calculus, providing insights into paleoethnobotanical history (Hardy K, Blakeney T, 2009; Blatt SH, Redmond BG etal. 2011). Evidence for the introduction of domesticated plants in 6,600 BC is buried in dental calculus (Cristiani E, Radini A et al. 2016). The consumption of fish and plants is revealed by stable isotope and dental calculus analyses of mesolithic foragers (Cristiani E, Radini A, Boric D et al. 2018).

Non-food deposits in dental calculus provide a wide variety of cultural and environmental evidence of the paleo-ambient environment (Radini A, Nikito E, et al. 2017). Analysis of the ancient oral microbiome embedded in dental calculus by genomic, proteomic and microscopic investigations reveal the evolution of dental pathogens, antibiotic resistance genes, bacterial virulence factors and immune defense proteins (Metcalf JL, Ursell LK, Knight R, 2014).

Neandertal habitats, diets and diseases have been inferred from the compounds found in dental calculus (Krief S, Daujeard C et al. 2015; Weyrich LS, Duchene $S$ et al. 2017). Identification of plant foods entrapped within dental calculus provides ecogeographic proof of the range of environmental habitats occupied by Neandertals (Power RC et al. 2018). Evidence for food cooking and medicinal applications have been contained in dental calculus ( Henry AG et al., 2011; Thatje S. 2012). The accretion of dental calculus entraps the contents of the ambient oral environment, there by providing a permanent paleontological record of past and present foods ingested. The oral microbiome is revealed by retained food and microbiological particles(Adler CJ et al. 2013). The ancient oral microbiome reveals pathogens and host immunity to local and systemic diseases (Warinner C, Rodrigues JF et al. 2014).

\section{Conclusion}

Reconstructing the repast of the past is now possible with the unprecedented capabilities presented by carbon isotope recognition within dental enamel and confocal scanning optical microscopy ( Lacruz 2007). Since teeth play a major role in dietary adapatations, they elucidate life styles, social activities, defense and sexual signaling. New paleofossil discoveries will reveal ancestry from tooth morphology (Scott GR, Pilloud MA et al. 2018). The new science of molecular anthropology, based on the DNA sequences of pulp tissues embedded within the developing dentition 
(paleogenomics) provides the information to create prehistory and evolutionary relationships (Heintzman PD, Soares AER et al. 2015). Dentitions are an anthropological "gold mine" of information of present and past histories. The capabilities of elucidating the evolution of the hominid dentition is greatly enhanced by phenomics, modularity and quantitative genetics (Hlusko LJ 2016). The new sciences of investigation of the past will provide insights into the evanescent mechanisms of biological evolution with the evidence derived from enduring dentitions as key players.

\section{REFERENCES}

[1] Adler CJ, Dobney K, Weyrich LS et al. Sequencing ancient calcified dental plaque shows changes in oral microbiota with dietary shifts of the Neolithic and Industrial revolutions. Nature Genet 2013; 45; 450-455.doi:10.1038/ng2536.

[2] Ahtiainen L, Uski I, Thesleff I, Mikkola ML. Early epithelial sigmaling center governs tooth budding morphogenesis. J Cell Biol 2016; 214(6):753-767.

[3] Balic A, Thesleff I. Tissue interactions regulating tooth development and renewal. Curr Top Dev Biol 2015; 115: 157-186.

[4] Blatt SH, Redmond BG, Cassman V, etal. Dirty Teeth and Ancient Trade: Evidence of Cotton Fibres in Human Dental Calculus from late Woodland, Ohio. Int. J. Osteoarchaeol. 2011; 21: 669-678.

[5] Buchtova M, Stembirek J, Glocova K. et al. Early regression of the dental lamina underlies the development of diphyodont dentitions. J Dent Res 2012; 91:491-498.

[6] Buckley S, Usai D, Jakob T, Radini A, Hardy K. Dental calculus reveals unique insights into food items, cooking and plant processing in prehistoric Central Sudan PLoS|One 9,e100808 (2014).

[7] Burnett SE, Irish JD, Fong MR. Wear's the problem? Examining the effect of dental wear on studies of crown morphology. In: Scott GR, Irish JD.(Eds). Anthropological Perspectives on Tooth Morphology: Genetics, Evolution, Variation. Cambridge, Cambridge University Press. 2013.

[8] Chen D, Blom H, Sanchez S et al. Development of cyclic shedding teeth from semi-shedding teeth: the inner dental arcade of the stem osteichthyan Lophosteus. R.Soc.Open Sci. 2017. 4:161084. doi. org/10.1098/rsos.161084.
[9] Choi C. Early human diets. ProcNatAcadSci. 2013. doi:10.1073/pnas.1310299110.

[10] Cristiani E, Radini A, Boric D, etal Dental Calculus and Isotopes Provide Direct Evidence of Fish and Plant Consumption in Mesolithic Mediterranean. Scientific Reports 2018; 8:8147; doi:10.1038/ s41598-018-06045-9

[11] Cristiani E, Radini A, Edinborough M, etal. Dental Calculus Reveals Mesolithic Foragers in the Balkans Consumed Domesticated Plant Foods. 2016, www. pnas.org/cgi/doi/10.1073/pnas.1603477113

[12] Currie PJ. Bird-like characteristics of the jaws and teeth of Troodontid theropodia (Dinosauria saurischian) J. Vertebr Paleontol 1987.;7:72-81.

[13] Dumont M. Tafforeau P, Bertin T et al. Synchrotron imaging of dentition provides insights into the biology of Hesperornis and Ichthyornis, the "last" toothed birds. BMC Evol Biol 2016; 16:178-206.

[14] Duval M, Grun R. Are published ESR dose assessments on fossil tooth enamel reliable? Quaternary Geochronol 2016; 31:19-27.

[15] Eng CM, Lieberman DE, Zink KD, Peters MA. Bite force and occlusal Stress production in hominin evolution. Am J Phys Anthrop 2013; 151:544-557.

[16] Field DJ, Hanson M, Burnham D et al. Complete Ichthyornis skull illuminates mosaic assembly of the avian head. Nature 2018; 557: 96-100.

[17] Fiorenza l, Benazzi s et al. Molar macrowear reveals Neanderthal Eco-geographical dietary variation. PLoS|One 62011. doi.org/10.1371/ journal.pone 0014769.

[18] Frayer DW, Monge J, Prehistoric dentistry? P4 rotation, partial M3 impaction, toothpick grooves and other signs of manipulation in Krapina Dental Person 20. Bull Int Assoc Paleodont. 2017. 11(1):1-10. dental evolution. Scientific Reports 2018. 8:5870. Doi:10.1038/s41598-018-24283-S.

[19] Green DR, Green GM, Colman AS etal. Synchrotron imaging and Markov Chain Monte Carlo reveal tooth mineralization patterns PLoS One 12 (10) Oct 2017. Article e0186391.

[20] Greenfield HJ, Shai I, et al. Earliest evidence for equid bit wear in the ancient Near East: The "ass" from Early Bronze Age Tell es-Safi/Gath, Isreal PLoS|One 2018;doi.org/10.1371/journal. pone.0196335. 
[21] Greenfield HJ, Shai I, et al. Earliest evidence for equid bit wear in the ancient Near East: The "ass" from Early Bronze Age Tell es-Safi/Gath, Isreal PLoS|One 2018; doi.org/10.1371/journal. pone.0196335.

[22] Grine FE, Sponheimer M, Ungar P, Lee-Thorp J et al. Dental microwear and stable isotopes inform the paleoecology of extinct hominins. Am J Phys Anthrop. 2012; 148: 285-317.

[23] Guatelli-Steinberg D. What teeth reveal about human evolution. Cambridge. Cambridge Univer sity Press. 2016.

[24] Guatelli-Steinberg D. Dental anthropology. Am J Phys Anthrop 2018; 165:879-892.

[25] Hardy K, Buckley S et al. Neanderthal medics? Evidence for food, cooking and medicinal plants entrapped in dental calculus. Naturwissenschaften. 2012. 99(8):617-626.

[26] Hardy K, Blakeney T, Copeland L, etal. Starch Granules, Dental Calculus and New Perspectives on Ancient Diet. J Archaeological Science (2009); 36 248-255.

[27] Haridy Y, Le Blanc ARH, Reisz RR. The Permian reptile Opisthodontosaurus carrolli: a model for acrodont tooth replacement and dental ontogeny. J Anat. 2018. 232(3): 371-382.

[28] He Y, Makovicky PJ, Xu X, You H. High- resolution computed tomographic analysis of tooth replacement pattern of the basal neoceratopsian Liaoceratops yanzigouensis informs ceratopsian dental evolution. Scientific Reports 2018. 8:5870. doi:10.1038/s41598-018-24283-S.

[29] Heintzman PD, Soares AER, Chang D, Shapiro B. Paleogenomics. Rev Cell Biol Mol Med 2015; 1(3): 243-267.

[30] Henry AG, Brooks AS Piprno DR. Microfossils in calculus demonstrate consumption of plants and cooked foods in Neanderthal diets (Shanidar III, Iraq; Spy I and II, Belgium. Proc Nat Acad Sci 2011. 108(2): 586-491.

[31] Hlusko LJ. Elucidating the evolution of hominid dentition in the age of phenomics, modularity, and quantitative genetics. Ann Anat 2016; 203: 3-11.
[32] Hlusko LJ, Carlson JP, Chaplin G et al. Environmental selection during the last ice age on the mother-toinfant transmission of vitamin $\mathrm{D}$ and fatty acids through breast milk. Proc Nat Acad Sc 2018; 201711788. doi: 10.1073/pnas.1711788115.

[33] Hou Shilin, Jin Meng. A new eutriconodont mammal from the early Cretaceous Jehol Biota of Liaoning, China. Chinese Sci Bulletin 2014. 59(5-6); 546-553.

[34] Jarvinen E, Shimomura-Kuroki J, Balic A et al. Mesenchymal Wnt/B-catenin signaling limits tooth number Development 2018; 145:doi:10.1242/ dev.158048.

[35] Kague E, Witten PE, Soenens M et al. Zebrafish sp7 mutants show tooth cycling independent of attachment, eruption and poor differentiation of teeth. Dev Biol 2018; 435(2):176-184.

[36] Kaidonis JA. Tooth wear: the view of the anthropologist. Clin Oral Investig. 2008; 12: Supp1:21-26.

[37] Klukkert ZS, Dennis JC, M'Kirera F, Ungar PS. Dental topographic analysis of the molar teeth of primates. Methods Mol Biol 2012; 915:145-152.

[38] Krief S, Daujeard C et al. Flavouring food: the contribution of chimpanzee behavior to the understanding of Neanderthal calculus composition and plant use in Neanderthal diets. Antiquity 2015. 89(344): 464-471.

[39] Krueger KL, Ungar PS, Guatelli-Steinberg D et al. Anterior dental microwear textures show habitat-driven variability in Neandertal behavior. J Hum Evol 2017; 105:13-23.

[40] Kunatoi W, Ananpornruedo P et al. Making extra teeth: Lessons from TRPSI mutation. Am J Med Genet Part A. 2017; 173(1):99-107.

[41] Kuratani S, Adachi N, Wada N etal. Developmental and evolutionary significance of the mandibular arch and prechordal/premandibular cranium in vertebrates: revising the heterotopy scenario of gnathostome jaw evolution. J Anat. 2013; 222: 41-55.

[42] Lacruz RS. Enamel microstructure of the hominid KB5223 from Kromdraai South Africa Am J Phys Anthrop 2007; 132:175-182. 
Paleo-Odontology, Teeth as Chroniclers of Life Histories

[43] Lieverse A Diet and the Aetiology of Dental Calculus. Int. J. Osteoarchaeol. 1999; 9: 219-232

[44] Liu C, Gu S, Sun C. et al. FGF signaling sustains the odontogenic fate of dental mesenchyme by suppressing Beta-catenin signaling. Development 2013; 140 (21): 4375-85.

[45] Lopez-Torres S, Selig KR, et al. Dental topographic analysis of paromomyid (Plesiadapiformes, Primates) cheek teeth: more than 15 million years of changing surfaces and shiting ecologies. Historical Biology 2017. doi:10.1080/08912963.2017.1289378.

[46] Lucas P.W., Omar R, Al-Fadhalah et al. Mechanisms and causes of wear in tooth enamel: implications for hominin diets. J Roy Soc Interface. 2013. doi: 10.1098/rsif.2012.0923.

[47] Mahoney P. Human dental microwear from Ohal II (22,500-23, 500 BP) Southern Levant. Am J Phys Anthrop 2007; 132 (4): 489-500.

[48] Metcalf JL, Ursell LK, Knight R Ancient Human Oral Plaque Preserves a Wealth of Biological Data Nature Genet 2014; 46: 321-323

[49] Miyashita T. Fishing for jaws in early vertebrate evolution: a new hypothesis of mandibular confinement. Biol Rev 2015; 1(3): 611-657.

[50] Ortiz A, Bailey SE, Schwartz GT, Hublin J-J, Skinner MM. Evo-devo models of tooth development and the origin of hominoid molar diversity. Sci Adv 2018; 4:eaar2334.

[51] Ozga AT et al. Successful enrichment and recovery of whole mitochondrial genomes from ancient human dental calculus. Am J Phys Anthrop 2016; 160:220-228.

[52] Padian K. Evolutionary insights from an ancient bird. Nature 2018; 557-36-37.

[53] Percher A, Merceron G, Akoue G et al. Dental microwear textural analysis as an analytical tool to depict individual traits and reconstruction of the diet of a primate. Am J Phys Anthrop 2018; 165(1) 123-138.

[54] Power RC, Salazar-Garcia DC, Rubini M, Darlas A. et al. Dental calculus indicates widespread plant use within the stable Neanderthal dietary niche. J Hum Evol 2018; 119: 27-41.
[55] Radini A, Nikita E, Buckley S, et al. 2017 Beyond Food: The Multiple Pathways for Inclusion of Materials into Ancient Dental Calculus; Am J Phys Anthropol 2017; 162: 71-83

[56] Rasch LJ, Martin KJ, Cooper RL et al. An ancient dental gene set governs development and continuous regeneration of teeth in sharks. Dev. Biol. 2016; 415(2):347-370.

[57] Rucklin M, Donoghue PCJ. Romundina and the evolutionary origin of teeth. Biol Letters 2015; 11(6): 20150326 doi:10.1098/rsbl .2015. 0326.

[58] Scott R, Halcrow S. Investigating weaning using dental micrower analysis: A Review. J Archaeol Sci Reports 2017; doi: 10.1016/j.jasrep.2016.11.026.

[59] Scott GR, Pilloud MA, Navega D, Coelo JD, Cunha E, Irish JD. A New Web-based application for estimating ancestry from tooth morphology. Forensic Anthrop 2018; 1(1): 18-31.

[60] Sillen A, Balter V. Strontium isotopic aspects of Paranthropus robustus teeth. J Hum Evol.2018. 114:118-130.

[61] Slon V, Viola B, Renaud G et al. A fourth Denisovan individual. Science Adv 2017; 3(7): e1700186.

[62] Smith MM, Fraser GJ, Johanson Z. Origin of teeth in jawed vertebrates, InFocus Magazine - June 6, 2016 Issue 42 - https://www.rms.org.uk/study-read/ infocus-magazine.html doi: 10.22443/rms.inf.1.136

[63] Smith M, Riley A, Fraser GJ, Underwood C, Welton $\mathrm{M}$ et al. Early development of rostrum saw-teeth in a fossil ray tests classical theories of the evolution of vertebrate dentitions Proc Royal Soc B 2015; 282(1816) 20151628. doi: 10.1098 / rspb.2015.1628.

[64] Sperber GH. The Divination of Dentitions in Evolution. Phylogenetics Evol Biol.2013; 1:2. dx.doi.org/10.4172/2329-9002.1000109.

[65] Sperber GH. Dental wear: Attrition, Erosion and Abrasion. A Palaeo-odontological Approach. Dent J. 2017; 5:19-25.

[66] Sponheimer M. et al. Isotopic evidence of early hominin diets. Proc Nat Acad Sci 2013.; 110(26); 10513-10518. 
[67] Thatje S. Neanderthal medics? Evidence for food, cooking, and medicinal plants entrapped in dental calculus. Naturwissenschaften 2012; 99:617-626.

[68] Torices A, Wilkinson R, Arbor VM, Ruiz-Omenaca J, Currie PJ. Puncture-and-Pull Biomechanics in the Teeth of Predatory Coelurosaurian Dinosaurs. Curr Biol 2018; 28: 1-8.

[69] Tseng P, Napier B, Garbarini L. et al. Functional, RF-Trilayer Sensors for tooth-mounted, wire less monitoring of the oral cavity and food consumption. Adv Materials 2018. doi:10.1002/ ama. 201703257.

[70] Ungar PS, Krueger KL et al. Dental microwear texture analysis of hominins recovered by the Olduvai Landscape Paleoanthropology Project 1995-2007. J Hum Evol 2012. 63(2); 429-437.

[71] Ungar PS. Dental evidence for the diets of PlioPleistocene hominins, Am J Phys Anthrop 2011. 146: 47-62.

[72] Ungar PS. Teeth: A Very Short Introduction. 2014. Oxford. Oxford University Press.
[73] Ungar PS. Evolution's Bite. Princeton, NJ. 2017. Princeton University Press

[74] Ungar PS, Berger LR. Brief communication: Dental microwear and diet of Homo naledi. Am J Phys Anthrop 2018. 001-8. doi.org/10.1002/ajpa.23418.

[75] Ungar PS, Hartgrove CL et al. Dental topography and microwear texture in Sapajus apella. Biosurface Biotribology 2017; 3: 124-134.

[76] Warinner C, Rodrigues JFM et al. Pathogens and host immunity in the ancient human oral cavity. Nature Genet 2014; 46: 336-344.

[77] Weyrich LS, Dobney K, Cooper A. Ancient DNA analysis of dental calculus. J. Hum Evol 2015. 79:119-124

[78] Weyrich LS, Duchene S, Cooper A. Neanderthal behavior, diet, and disease inferred from ancient DNA in dental calculus. Nature 2017. 544:357-361.

[79] Zhu M, Ahlberg PE, Pan Z. et al. A Silurian maxillate placoderm illuminates jaw evolution. Science 2016. 354(6310): 334-336.

Citation: G. H. Sperber. Paleo-Odontology, Teeth as Chroniclers of Life Histories Study. Archives of Dentistry and Oral Health. 2018; 1(1): 29-36.

Copyright: (C) 2018 G. H. Sperber. This is an open access article distributed under the Creative Commons Attribution License, which permits unrestricted use, distribution, and reproduction in any medium, provided the original work is properly cited. 